\title{
Clinical Implications of a Neuropsychological Approach to Aphasia
}

\author{
Aura Kagan MA (Speech Pathology) (Witwatersrand); \\ Michael Saling PhD (Witwatersrand), $†$ \\ Margaret Marks Wahlhaus MA (Witwatersrand)* \\ * Department of Speech Pathology and Audiology, University of the Witwatersrand, Johannesburg. \\ $\uparrow$ Department of Psychology, University of the Witwatersrand, Johannesburg.
}

\begin{abstract}
'ABSTRACT
This paper deals with the clinical implications arising out of a study designed to evaluate Luria's approach to the cerebral organisation of higher mental functions such as language. The research took the form of four in-depth case studies of aphasic patients and involved a comparison of neuropsychological predictions as to the site-of-lesion with radiological findings (cranial computerised tomographic scanning). Correspondence was felt to be good in most instances, indicating that Luria's theory provides a valid framework within which to relate clinical symptomatology and focal brain damage. The fact that Luria places clinical practice on a firm theoretical foundation is seen as being advantageous and is discussed in relation to assessment and therapy.
\end{abstract}

\section{OPSOMMING}

In hierdie studie word Luria se benadering tot die organisasie van hoër-verstandelike funksies soos onder andere, taal, evalueer. Die kliniese implikasies van die studie kom veral onder die soeklig. Die navorsing het uit vier gevalle studies van afatiese patiënte bestaan. 'n Vergelyking is tussen die neuropsigologiese simptome as voorspelling van die lokus van die letsel, en radiologiese bewysings, getref. Die ooreenkoms tussen die neuropsigologiese voorspelling en die lokus van die letsel was in meeste gevalle goed. Dit dui dus aan dat Luria se teorie 'n geldige raamwerk verskaf waarbinne kliniese simptomatologie en fokale breinskade gekoppel kan word. Die kliniese praktyk wat Luria op so 'n vaste teoretiese grondslag bou, word met betrekking tot diagnose en behandeling bespreek.

The speech clinician involved in the assessment and remediation of aphasia is confronted by a bewildering array of approaches to this complex disorder. This paper focuses on some clinical implications arising out of a study** designed to evaluate, within the context of speech pathology, the neuropsychological approach developed by Luria, who has been described as "this century's leading Soviet figure in aphasiology". ${ }^{8}$ According to Hatfield, ${ }^{8}$ Luria is one of the few leading aphasiologists who has combined clinical practice with theory. This is seen as a major advantage, but it does imply that an understanding of the general neuropsychological principles upon which Luria based his work is essential for the clinician who wishes to use this approach. A brief resumé of theoretical aspects relevant to this paper follows.

Luria viewed his work on the organisation of higher mental functions in the brain as incorporating the positive aspects of two opposed approaches to the subject. He felt that neither the mechanistic narrow view, given its major impetus by the work of Broca,' nor the integral or noetic view, supported by authorities such as Goldstein, ${ }^{5}$ successfully accounted for the cerebral organisation of higher mental function. Both views in Luria's opinion contributed to misunderstandings of this complex subject.
In a re-examination of concepts such as function, localisation and symptom, Luria retained and integrated parts of both the extreme views mentioned above, while successfully avoiding the less desirable aspects, namely, the idea that complex mental processes can be located in a single focal area of the brain on the one hand, and that such activities involve the whole brain in an undifferentiated fashion on the other.

According to Luria, ${ }^{12 .}{ }^{13}$ one should conceptualise the higher mental functions as functional systems with an extremely complex composition. The performance of any such mental activity necessarily involves the co-operation of many different parts of the brain.

Luria divides the brain into three main functional units. These units and their further subdivision into hierarchically arranged cortical zones, are described in detail in his works ${ }^{\mathrm{i} 2,13}$ and are represented schematically in Figure 1. Speech and language are thus viewed as complex functional systems to which many different cortical areas contribute (See Table 1). Luria ${ }^{13}$ refers to these cortical areas as "links" within the functional system. Damage to any one of these areas affects its ability to function optimally and it thus becomes a weak or broken link within the chain of the functional system. Although any damaged link

* This study formed part of the first author's MA dissertation entitled "A Neuropsychological Approach to Assessment in Aphasia". 


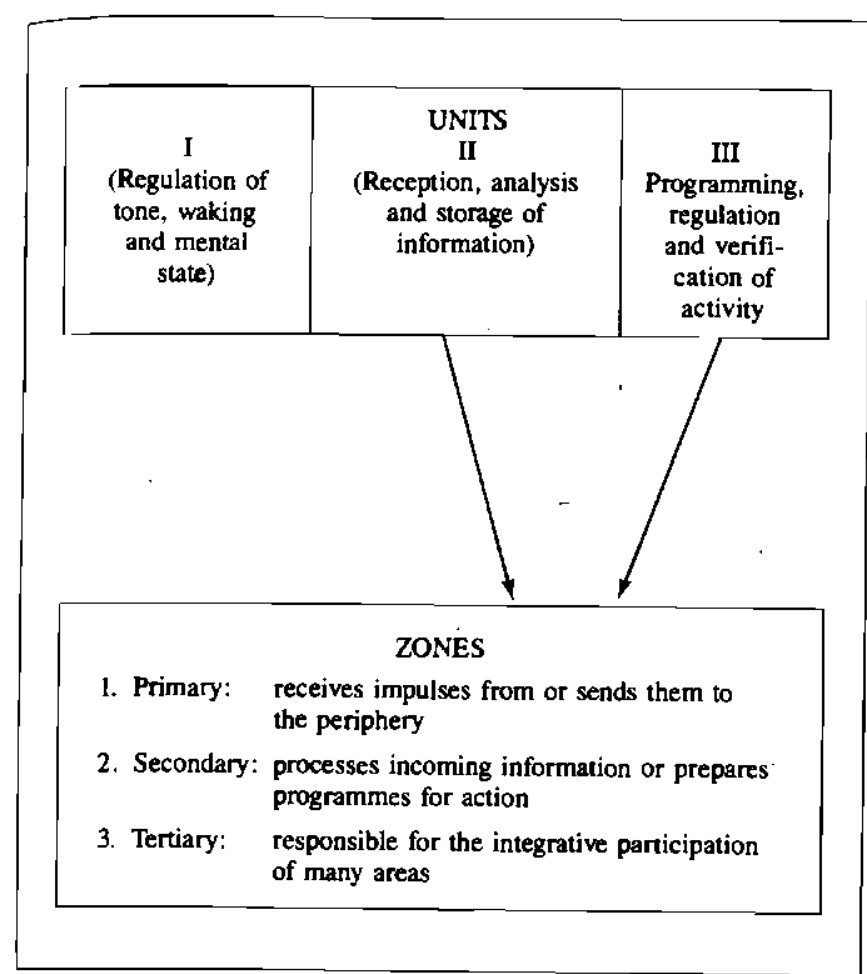

Figure 1 Schematic view of Luria's division of the brain into units and zones.

will affect the functional system, the effects will vary depending upon the particular link involved. The interference with the normal function of a specified cortical area results in a primary or fundamental problem. The secondary or systemic effect of this primary problem is the breakdown in the functional systems to which the area normally contributes.

Two points should be noted at this stage. First, what appears to be the same symptom complex, may actually be related to one of several primary problems. For example, the common aphasic symptom of word-finding difficulty may be caused by a breakdown in phonemic hearing, problems with simultaneous synthesis, or difficulties at the articulatory level. Second, because the function of a specific cortical area may be a link in several functional systems, a focal lesion might result in a group of symptoms which are seemingly unrelated. However, appropriate neuropsychological analysis reveals that the symptom complex consists of "externally heterogeneous but, in fact, internally' interconnected symptoms". ${ }^{13}$ For ex- ample, a lesion of the overlapping tertiary zone in Unit II results in a specific primary problem, namely, difficulty with simultaneous synthesis. However secondary or systemic effects include a problem with logical-grammatical relationships as well as acalculia. Rather than attempting to localise complex functional systems such as receptive or expressive language, an attempt should be made to identify the various focal areas of the brain which make a specific contribution to the system as a whole. The clinician who is able to localise the lesion and who understands how the resultant primary problem may affect the functional system under consideration, is then in a position to plan appropriate treatment. Thus within Luria's framework, a classifactory label attached to an aphasic patient is not merely descriptive but is rather an indication of the primary problem underlying the presenting symptom cluster (see Table 2).

Luria ${ }^{14}$ himself recognised the need to evaluate his work in terms of some objective criterion and it was with this in mind that the present research evolved. The study was designed to assess Luria's views on the manner in which symptomatology relates to brain damage. More specifically, the aim was to compare the site-of-lesion in aphasic patients as ascertained by Luria's neuropsychological tests, with the results of radiological findings based on cranial computerised tomography (C.T.) scanning. The study itself will be described very briefly and will be followed by a discussion of clinical implications.

\section{METHOD}

This research took the form of four in-depth case-studies.

\section{SUBJECTS}

All subjects were diagnosed as aphasic by a speech therapist and a neurologist. Etiology was required to be a CVA resulting in a focal lesion that could be observed on a cranial CT scan. The upper age-limit was set at 55 years and hearing was required to be within normal limits. A minimum period of three months had to have elapsed since the onset of the CVA to allow for spontaneous recovery in accordance with the study by Demeurisse, Demol, Derouck, deBeuckelaer, Coekaerts and Capon. ${ }^{4}$ See Table 3 for a description of the subjects.

\section{PROCEDURE}

Subjects were scanned (cranial CT scanning) in order to establish the presence of a focal lesion. As this was a blind

\section{Table 1 An illustration of some aspects of the roles played by different cortical units and zones in the functional system of speech} and language (with respect to leftddominant hemisphere function)

\begin{tabular}{|l|l|l|l|}
\hline UNIT I & \multicolumn{2}{|l|}{ Maintains the optimal level of cortical tone necessary for the functioning of the systems of speech and language } \\
\hline $\begin{array}{l}\text { UNIT II } \\
\text { Auditory analyser }\end{array}$ & $\begin{array}{l}\text { Zone 1 } \\
\text { Receives auditory impulses } \\
\text { Visual analyser } \\
\begin{array}{l}\text { Tactile-kinaesthe- } \\
\text { tic analyser }\end{array}\end{array}$ & $\begin{array}{l}\text { Receives visual impulses } \\
\text { Receives sensory impulses } \\
\text { Recognition and processing of speech } \\
\text { sounds or phonemes } \\
\text { Visual gnostic functions } \\
\text { Tactile-kinaesthetic gnostic functions }\end{array}$ & $\begin{array}{l}\text { Zone 3 } \\
\text { Integration of successive input }\end{array}$ \\
\hline UNIT II & $\begin{array}{l}\text { Zone 1 } \\
\text { Outlet channel for movement } \\
1\end{array}$ & $\begin{array}{l}\text { Zone 2 } \\
\text { Planning of movement }\end{array}$ & $\begin{array}{l}\text { Zone } 3 \\
\text { Regulation and verification of complex } \\
\text { behaviour }\end{array}$ \\
\hline
\end{tabular}


Table 2 Luria's classification of aphasia as related to primary problems and areas of cortical damage

\begin{tabular}{|c|c|c|}
\hline Type of aphasia & Primary problem & Cortical area \\
\hline Efferent motor & Skilled sequential movements & Pre-central \\
\hline Afferent motor & Motor kinaesthetic afferentation & Post-central \\
\hline Dyлamic & Speech drive & Frontal lobes \\
\hline Sensory & Phonemic hearing & Superior, posterior temporal lobe \\
\hline Acoustico-mnestic & Audio-verbal m€mory & Middle temporal Jobe \\
\hline Semantic & $\begin{array}{l}\text { Simultaneous synthesis affecting } \\
\text { quasi-spatial operations }\end{array}$ & $\begin{array}{l}\text { Posterior inferoparietal lobe } \\
\text { (tertiary, overlapping zone) }\end{array}$ \\
\hline
\end{tabular}

Table 3 Description of subjects

\begin{tabular}{|c|c|c|c|c|}
\hline Subjects & 0 & $\mathbf{P}$ & V & D \\
\hline Age at time of testing & 49 years & 50 years & 44 years & 23 years \\
\hline $\operatorname{Sex}$ & male & male & female & male \\
\hline Time elapsed since onset & 9 months & 5 months & $1 \frac{2}{4}$ years & almost 2 years \\
\hline $\begin{array}{l}\text { Immediate effects of the } \\
\text { CVA including progress } \\
\text { in first } 3 \text { weeks }\end{array}$ & $\begin{array}{l}\text { Could not speak for } \\
\text { first } 3 \text { days. Recovered } \\
\text { slowly }\end{array}$ & $\begin{array}{l}\text { Could not speak for } \\
\text { first } 3 \text { days. Recovered } \\
\text { slowly. Paralysis of right } \\
\text { upper limb - recovered } \\
\text { completely }\end{array}$ & $\begin{array}{l}\text { Could not speak. } \\
\text { Dense right hemiplegia. }\end{array}$ & $\begin{array}{l}\text { Coma for } 2 \frac{1}{2} \text { weeks. } \\
\text { Right-sided hemiplegia. }\end{array}$ \\
\hline Speech therapy & $\begin{array}{l}\text { Immediately after stroke } \\
\text { for } 4 \text { months }\end{array}$ & - & $\begin{array}{l}\text { Immediately after stroke. } \\
\text { Discontinued after } 1 \text { year }\end{array}$ & $\begin{array}{l}\text { Immediately after stroke } \\
\text { until the present time }\end{array}$ \\
\hline Pre-morbid conditions & $\begin{array}{l}\text { Heart condition ( } 3 \\
\text { previous heart attacks). } \\
\text { High blood pressure. } \\
\text { Diabetes diagnosed at age } \\
35 \text { years }\end{array}$ & - & - & - \\
\hline $\begin{array}{l}\text { Post-morbid complications } \\
\text { in addition to aphasia }\end{array}$ & $\begin{array}{l}\text { Athetoid movements of } \\
\text { right hand. Hemianopia }\end{array}$ & - & Severe hemiplegia & $\begin{array}{l}\text { Residual hemiplegia and } \\
\text { hemiparesis. Jacksonian } \\
\text { epilepsy }\end{array}$ \\
\hline Pre-morbid handedness & Right & Right & Right & Left \\
\hline $\begin{array}{l}\text { Drugs taken at the time of } \\
\text { testing }\end{array}$ & Aldomet, Isoptin, Syndol & Persanton, Librium & Epinutin & $\begin{array}{l}\text { Epinutin, Persanton, } \\
\text { Aspirin, Tegretol }\end{array}$ \\
\hline Home Language & Afrikaans & English & Afrikaans & English \\
\hline Pre-morbid occupation & Lawyer & Sheet-metal worker & Secretary & University student \\
\hline Present occupation & - & Same & Housewife & Stores issues clerk \\
\hline $\begin{array}{l}\text { Pre-morbid educational } \\
\text { level }\end{array}$ & University degree & Standard five & $\begin{array}{l}\text { Matriculation. Secretarial } \\
\text { diploma }\end{array}$ & University student \\
\hline
\end{tabular}

study, the researcher did not have access to the scans at this stage, and thus had no knowledge of the extent or localisation of the lesion. Luria's Neuropsychological Investigation $(\mathrm{LNI})^{2,3}$ was then administered and analysed. The details of the neuropsychological process of analysis have been described in Kagan. ${ }^{9}$ Once a neuropsychological decision as to the site-of-lesion for each subject had been reached, this was handed to a person uninvolved in the study. The cranial CT scans were then made available and were interpreted by a radiologist. A conclusion as to the correspondence between the neuropsychological and radiological findings was reached.

\section{RESULTS}

The results of the study are summarised in' Table 4 which compares neuropsychological predictions as to the site-of-lesion with radiological findings (cranial CT scans). Bearing in mind normal individual variation in thé cerebral organisation of higher mental functions, as well as subject characteristics encountered in this study (for example, one left-handed subject and one with a premorbidly low level of intellectual function), the correspondence between the neuropsychological and radiological findings is felt to be good. However, mention must be made of instances of non-agreement. In certain cases, 
Table 4 Summary of results comparing neuropsychological and radiological findings for all four subjects

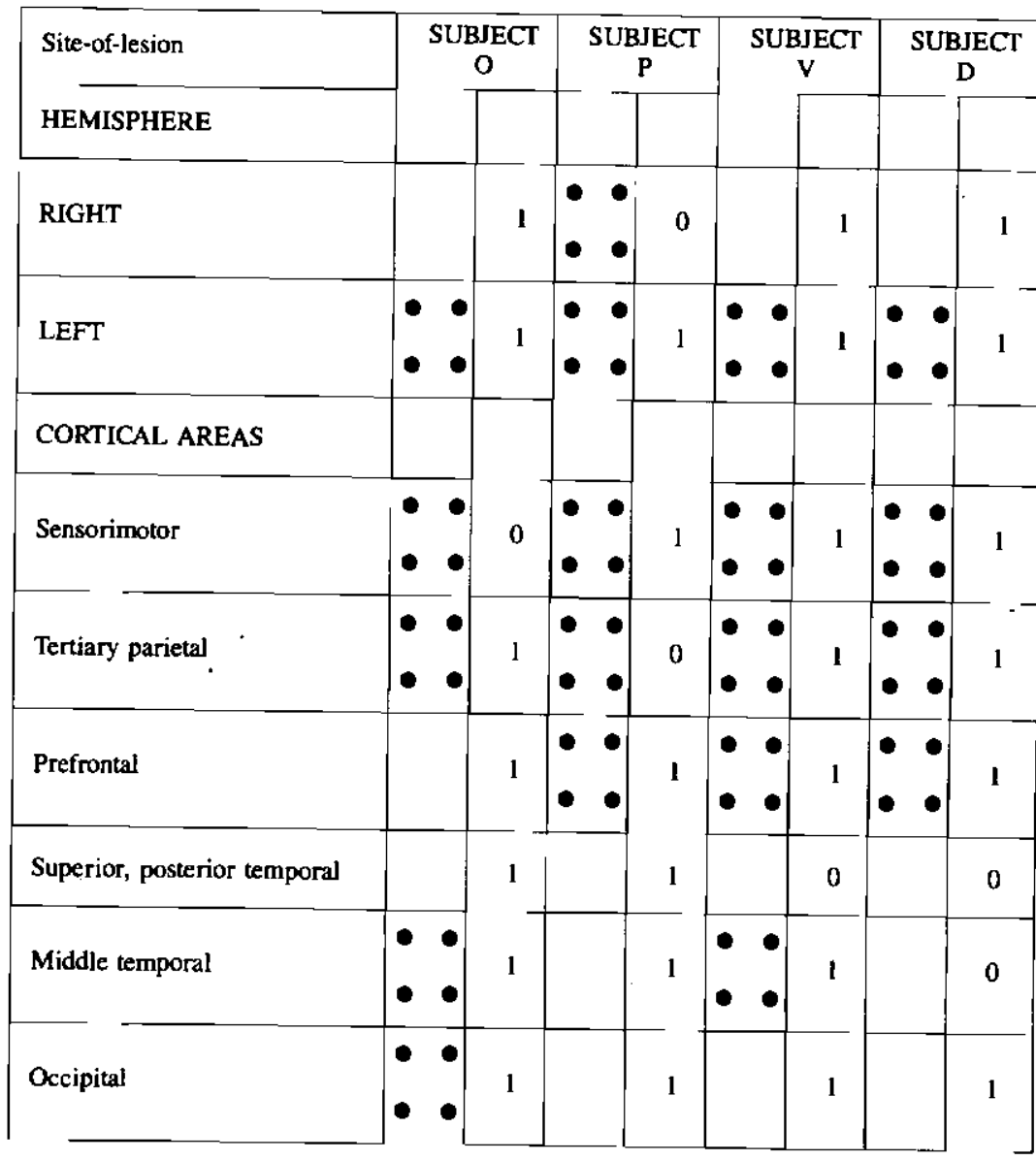

\section{KEY}

Neuropsychological Findings

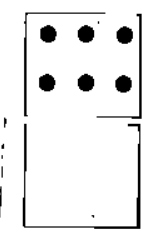

Indication of damage

Contra-indication of damage
Radiological Confirmation of Neuropsychological Findings

1 Confirmed

o Not confirmed there was no evidence of structural damage to support clinical symptomatology. In this instance, it is possible that there is damage that has not been picked up on the scans. It should be borne in mind that the scanning techniques used here provide a static representation of extant neuropathology. It is our belief that neuroradiological procedures which can detect physiological or functional change such as blood-flow, for example, might correlate better with neuropsychological dysfunction, than the static structural damage observed on the scans used in this study.

It is felt to be more important to account for the cases in which there is a definite indication of damage on the scan but no evidence of the clinical symptoms one would expect from such damage. In both subjects $V$ and $D$, for example, there was little or no clinical manifestation of observed damage to the $D$ superior posterior temperal lobe (Wernicke's area). In subject $D$ who was premorbidly left-handed, there is a strong possibility of bilateral representation in the premorbid cerebral organisation of language, lending support to work done by Hardyck. ${ }^{7}$ However, it is more difficult to account for the same situation arising in Subject $V$, who is a righthander. The fact that damage to Wernicke's area did not result in the expected symptomatology, despite good correspondence in other areas, leads one to consider the possibility of a premorbid bilateral representation of language in this subject.

Despite the above instances of non-agreement the fact that the principles of Luria's neuropsychological analysis were useful in arriving at the site-of-lesion in most cases, indicates that his theory of functional localisation, in which the concept of the primary problem plays such a central role, is a valid means of relating observed symptomatology to focal brain damage.

\section{DISCUSSION}

This result has clinical implications for the speech clinician dealing with aphasia as Luria's views on diagnosis and therapy are logically related to his theory. First, as regards classification, Luria's approach ${ }^{12}{ }^{13}$ differs from many traditional approaches e.g. 16 . 
While accurate classification is stressed, this does not, as mentioned previously, merely involve the attaching of descriptive labels. Rather, classification gives an indication of the real (primary) problem or problems underlying the often confusing picture presented by the patient. As can be seen from Table 5 , although the types of aphasia represented range from the highly specific, such as afferent motor aphasia, to those of a broader nature, such as dynamic and semantic aphasia, they all relate to underlying brain damage in the same fashion, namely, focal brain damage results in specific primary problems which are manifested in the symptoms we observe.
One of the advantages of Luria's approach is that it enables one to be specific. For example, the commonly used term 'global aphasia' indicates that there are gross expressive and receptive language defects related to an extensive lesion probably involving both anterior and posterior parts of the brain. ${ }^{10}$. 15 It might be far more useful clinically to have more detail about the exact extent of the lesion and the primary problems which need to be tackled. In other words, global aphasia should be viewed as a complex combination of several primary problems rather than as an undifferentiated whole. Similarly it would be more useful theoretically and clinically to classify complex

Table 5 Classification of subjects according to the primary problem and types of aphasia

\begin{tabular}{|c|c|c|}
\hline Subject & Primary Problem & Type of aphasia in terms of Luria's classification \\
\hline 0 & $\begin{array}{l}\text { Visual agnosia for letters } \\
\text { Spatial and quasi-spatial difficulties } \\
\text { Mild audio-verbal memory difficulties }\end{array}$ & $\begin{array}{l}\text { Semantic aphasic } \\
\text { Mild acoustico-mnestic aphasia }\end{array}$ \\
\hline $\mathbf{P}$ & Some quasi-spatial problems & Mild semantic aphasia \\
\hline $\mathbf{V}$ & $\begin{array}{l}\text { Efferent and afferent organization of } \\
\text { movernent and speech } \\
\text { Quasi-spatial difficulties } \\
\text { Audio-verbal memory } \\
\text { Regulation of movements and actions }\end{array}$ & $\begin{array}{l}\text { Efferent motor aphasia } \\
\text { Semantic aphasia } \\
\text { Acoustico-mnestic aphasia } \\
\text { Possibility of dynamic aphasia }\end{array}$ \\
\hline D & $\begin{array}{l}\text { Efferent and afferent organization of } \\
\text { movement and speech } \\
\text { Quasi-spatial difficulties }\end{array}$ & $\begin{array}{l}\text { Efferent aphasia } \\
\text { Afferent aphasia } \\
\text { Semantic aphasia }\end{array}$ \\
\hline
\end{tabular}

Table 6 Primary problems and effects relevant for therapy (Subject $V$ )

\begin{tabular}{|l|l|l|l|l|}
\hline Primary problem & $\begin{array}{l}\text { Efferent and afferent } \\
\text { organization of movement } \\
\text { and speech }\end{array}$ & $\begin{array}{l}\text { Simultaneous synthesis } \\
\text { (quasi-spatial problems) }\end{array}$ & Audio-verbal difficulties \\
\hline $\begin{array}{l}\text { Effects on speech and } \\
\text { language }\end{array}$ & $\begin{array}{l}\text { Severe articulation problems } \\
\text { Absence of narrative } \\
\text { speech }\end{array}$ & $\begin{array}{l}\text { Quasi-spatial functions, for } \\
\text { example, difficulty in } \\
\text { understanding logical-gram- } \\
\text { matical speech }\end{array}$ & $\begin{array}{l}\text { Difficulty with series of } \\
\text { verbal stimuli }\end{array}$ & $\begin{array}{l}\text { Possibility of problems with } \\
\text { internal speech }\end{array}$ \\
\hline $\begin{array}{l}\text { Otber major effects of } \\
\text { relevance to the speech } \\
\text { clinician }\end{array}$ & Hemiplegia & \begin{tabular}{l} 
Problems of,motivation, atten- \\
tion, perseveration, attention \\
to irrelevant stimuli, inhibition \\
of actions, etc. \\
\hline
\end{tabular}
\end{tabular}

Some difficulties, such as naming and comprehension in some instances cannot be related to one specific primary problem in this subject. These
difficulties may be due to a combination of some or all of the above primary problems.

Table 7 Primary problems and effects relevant for therapy (Subject O)

\begin{tabular}{|l|l|l|l|}
\hline Primary problem & $\begin{array}{l}\text { Simultaneous synthesis } \\
\text { (quasi-spatial problems) }\end{array}$ & Agnosia for letters & Mild audio-verbal difficulties \\
\hline $\begin{array}{l}\text { Effects on speech and } \\
\text { language }\end{array}$ & $\begin{array}{l}\text { Word-finding difficulty } \\
\text { Some difficulty with } \\
\text { confrontation naming } \\
\text { Mild problems with logical- } \\
\text { grammatical structures }\end{array}$ & $\begin{array}{l}\text { Severe alexia } \\
\text { retention of series of } \\
\text { auditory material in the } \\
\text { absence of semantic cues }\end{array}$ \\
\hline $\begin{array}{l}\text { Other major effects of } \\
\text { relevance to the speech } \\
\text { clinician }\end{array}$ & & Hemianopia \\
\hline
\end{tabular}


cases of aphasia, such as Broca's, in terms of the primary problems involved (see Table 5) instead of grouping them together in a broad symptomatological category often inaccurately related to an isolated focal area of the cortex.

Second, in order to plan therapy appropriately, it is necessary to relate the primary problem to speech and language. Other effects of the primary problem while not directly related to speech and language, must also be taken into account. The following charts (see Tables 6 and 7) have been drawn up as an illustration of one way in which the speech clinician can relate the primary problem to the overall symptom complex.

Subjects $V$ and $O$ have been chosen as examples because they represent different levels of severity and complexity. In the former case $(V)$, brain-damage was extensive and the clinical picture highly complex, making it difficult to identify the underlying primary problems. In the latter case $(0)$, the primary problems were relatively easy to identify.

These therapy charts need to be individually tailored for each patient. Being able to isolate the primary problem does not mean that the entire symptom profile can be predicted, although symptoms should be able to be explained in terms of the primary problem. The neuropsychological examination, in addition to giving information about the site-of-lesion, enables the clinician to be fairly specific about the functional effects of this damage in the individual being examined. For example in subject $\boldsymbol{V}$, there was evidence of both efferent and afferent motor aphasia. However, the latter predominated and would therefore require more attention initially. It was observed, that if this subject was able to circumvent kinaesthesis by compensating with her strong visual abilities or a combination of audio-visual stimulation for example, she was able to articulate reasonably well. This fact should be used in constructing an appropriately graded therapy programme. In addition, the major effects of prefrontal damage in the case of Subject $V$ would definitely affect therapy adversely and would make for a far less favourable prognosis. Examples of the symptoms being referred to are problems of motivation, attention to irrelevant stimuli, and inhibition of actions, among other things.

The clinician must therefore be aware of which problems are of major importance and require most attention. It must be understood that 'important' in this case refers to the fact that the particular problem is having a major effect on the patient's ability to communicate. For example, in the case of Subject $O$ (see Table 7), the mild audio-verbal difficulties noted did not affect communication significantly.

\section{CONCLUSION}

The implications of the findings of the study reported here have been discussed in relation to classification and therapy. Although these have been discussed separately, it is hoped that the logical and cohesive nature of Luria's neuropsychological theory is evident in the way in which these topics relate to each other.

The fact that Luria places clinical practice on a firm theoretical foundation is seen as being advantageous to the speech clinician, who, with her theoretical background and access to clinical material, has in turn a significant contribution to make to the neuropsychological study of aphasia. Fur- ther research in the field would be usefully augmented by clinical studies evaluating, in particular, Luria's approach to assessment and remediation in aphasia. Feedback from such studies could for example be used to remodel aspects of Luria's classification of aphasia which do not seem to tie in with clinical reality.

On a more practical level, Luria's work should be made available in a format especially designed for use by the speech clinician involved in the field of aphasia.

Although a considerable investment of time and energy is required of the speech clinician interested in applying Luria's approach, the effort is felt to be worthwhile "for practicalminded field speech pathologists, who are willing and flexible enough to try to understand the underlying philosophy".

\section{ACKNOWLEDGEMENTS}

Financial assistance from the Medical Research Council and the George Elkin Bequest is gratefully acknowledged as are a Senior Bursary and Freda Lawenski Scholarship Fund Grant administered by the University of the Witwatersrand, Johannesburg.

\section{REFERENCES}

1. Broca, P. Remarques Sur le Siége de la Faculté du Langage Articulé, Suivies d'une Observation d'Aphémie (Perte de la Parole). Bulletins de la Societe Anatomique de Paris, 1861, 6, 330-357.

2. Christensen, A. L. Luria's Neuropsychological Investigation: Text, Copenhagen: Munksgaard, 1974.

3. Christensen, A. L. Luria's Neuropsychological Investigation: Manual, Copenhagen: Munksgaard, 1975.

4. Demeurisse, G., Demol, O., Derouck, M., deBeuckelaer, R., Coekaerts, M. J. \& Capon, A. Quantitative Study of the Rate of Recovery from Aphasia due to Ischemic Stroke. Stroke, 1980, H, 455-458.

5. Goldstein, K. Language and Language Disturbances. New York: Grune \& Stratton, 1948.

6. Goodglass, H. \& Kaplan, E. The Assessment of Aphasia and Related Disorders. Philadelphia: Lea \& Febiger, 1972.

7. Hardyck, C. A Model of Individual Differences in Hemispheric Functioning. In H. Whitaker \& H. A. Whitaker (Eds.) Studies in Neurolinguistics, Vol. 3, New York: Academic Press, Inc., 1977.

8. Hatfield, F. M. Analysis and Remediation of Aphasia in the U.S.S.R.: The Contribution of A. R. Luria. J Speech Hear Dis, 1981, 46, 338-347.

9. Kagan, A.A Neuropsychological Approach to Assessment in Aphasia. Unpublished dissertation submitted to the Department of Speech Pathology and Audiology, University of the Witwatersrand, Johannesburg, South Africa, 1982.

10. Kertesz, A. Aphasia and Associated Disorders: Taxonomy, Localization and Recovery. New York: Grune \& Stratton, Inc., 1979.

11. Luria, A. R. Traumatic Aphasia: Its Syndromes, Psychology and Treatment. The Hague: Mouton, 1970. 
12. Luria, A. R. The Working Brain: An Introduction to Neuropsychology. Harmondsworth, Middlesex: Penguin Books ltd., 1973.

13. Luria, A. R. Higher Cortical Functions in Man. 2nd ed. New York: Basic Books, Inc., 1980.

14. Luria, A. R. \& Majovski, L. V. Basic Approaches Used in American and Soviet Clinical Neuropsychology. Am Psychol, 1977, 32, 959-968.
15. Naeser, M. A. and Hayward, R. W. Lesion Localisation in Aphasia with Cranial Computed Tomography and the Boston Diagnostic Aphasia Exam. Neurology, 1978, 28, 545-551.

16. Schuell, H., Jenkins, J. J. \& Jiménez-Pabón, E. Aphasia in Adults. New York: Harper \& Row, 1964. 